\title{
SPATIAL COMPUTING: ISSUES IN VISION, MULTIMEDIA AND VISUALIZATION TECHNOLOGIES
}




\section{SERIES IN MACHINE PERCEPTION AND ARTIFICIAL INTELLIGENCE*}

Editors: H. Bunke (Univ. Bern, Switzerland)

P. S. P. Wang (Northeastern Univ., USA)

Vol. 17: Applications of Al, Machine Vision and Robotics (Eds. K. L. Boyer, L. Stark and H. Bunke)

Vol. 18: VLSI and Parallel Computing for Pattern Recognition and $\mathrm{Al}$ (Ed. N. Ranganathan)

Vol. 19: Parallel Image Analysis: Theory and Applications (Eds. L. S. Davis, K. Inoue, M. Nivat, A. Rosenfeld and P. S. P. Wang)

Vol. 20: Picture Interpretation: A Symbolic Approach (Eds. S. Dance, T. Caelli and Z.-Q. Lin)

Vol. 21: Modelling and Planning for Sensor Based Intelligent Robot Systems (Eds. H. Bunke, T. Kanade and H. Noltemeier)

Vol. 22: Machine Vision for Advanced Production (Eds. M. Pietikainen and L. F. Pau)

Vol. 23: Machine Learning and Perception (Eds. G. Tasini, F. Esposito, V. Roberto and P. Zingarett)

Vol. 24: Spatial Computing: Issues in Vision, Multimedia and Visualization Technologies

(Eds. T. Caelli, Peng Lam and H. Bunke)

Vol. 25: Studies in Pattern Recognition Memorial Volume in Honor of K S Fu (Eds. H. Freeman)

Vol. 26: Neural Network Training Using Genetic Algorithms (Eds. L. C. Jain, R. P. Johnson and A. F. J. van Rooij)

\section{Forthcoming}

Vol. 27: Intelligent Robots - Sensing, Modelling \& Planning (Eds. B. Bolles, H. Noltemeier and H. Bunke)

Document Analysis II

(Eds. J. J. Hull and S. Taylor)

Pattern Recognition

(A. Kandel and M. Friedman)

Bankcheck Processing

(Eds. S. Impedovo, P. S. P. Wang and H. Bunke)

\footnotetext{
"For the complete list of titles in this series, please write to the Publisher.
} 
Series in Machine Perception and Artificial Intelligence - Vol. 24

\title{
SPATIAL COMPUTING: \\ ISSUES IN VISION, MULTIMEDIA AND VISUALIZATION TECHNOLOGIES
}

\author{
Editors \\ T Caelli \& Peng Lam \\ Department of Computer Science \\ Curtin University of Technology \\ 1987 Perth, WA, Australia

\section{Horst Bunke} \\ Institut für Informatik und Angewandte Mathematik \\ Universität Bem \\ Neubrückstrasse 10, CH-3012 \\ Bern, Switzerland
}




\section{Published by}

World Scientific Publishing Co. Pie. Lid.

P O Box 128, Farrer Road, Singapore 912805

USA office: Suite 1B, 1060 Main Street, River Edge, NJ 07661

UK office: 57 Shelton Street, Covent Garden, London WC2H 9HE

\section{British Library Cataloguing-in-Publication Data}

A catalogue record for this book is available from the British Library.

\section{SPATIAL COMPUTING: ISSUES IN VISION, MULTIMEDIA AND VISUALIZATION TECHNOLOGIES}

Copyright (1) 1997 by World Scientific Publishing Co. Pte. Ltd.

All rights reserved. This book, or parts thereof. may not be reproduced in any form or by any means, electronic or mechanical, including photocopying, recording or any information storage and retrieval system now known or to be invented, without written permission from the Publisher.

For photocopying of material in this volume, please pay a copying fee through the Copyright Clearance Center, Inc., 222 Rosewood Drivc, Danvers, MA 01923, USA. In this case permission to photocopy is not required from the publisher.

ISBN $981-02-2924-0$ 


\section{CONTENTS}

Foreword

T. Caelli, H. Bunke \& Peng Lam

Bayesian Paradigms in Image Processing

Z.-Q. Liu

Robot Navigation by Visual Dead-Reckoning: Inspiration From Insects

M. V. Srinivasan, J. S. Chahl \& S.W. Zhang

Assessing Feature Importance in the Context of Object Recognition

G. A. W. West

Geometric Variations: Analysis, Optimization and Control

B. T. Daniel, G. A. W. West $\mathcal{E}$ M. Cardew-Hall

Using Aspect Graphs to Control the Recovery and Tracking of

Deformable Models

S. J. Dickinson \& D. Metaxas

The Role of Machine Learning in Building Image Interpretation Systems

T. Caelli \& W. F. Bischof

Recent Advances in Graph Matching

H. Bunke \& B B. T. Messmer

Cooperative Spatial Reasoning for Image Understanding

T. Matsuyama $\mathcal{G}$ T. Wada

Human Lnderstanding Limits in Visualization

A. J. Maeder

A Strategy and Architecture for the Visualization of Complex Geographical Datasets

$M$. Gahegan \&s D. O'Brien

Visualizing Spatial Data: The Problem of Paradigms

P. K. Robertson

The Visitors Guide: A Simple Video Reuse Application

$K$. Shearer, S. Venkatesh \& D. Kieronska

Conceptual Representation for Multimedia Information

R. W. Smith, D. Kieronska \& S. Venkatesh 